\title{
Chlamydia trachomatis in the conjunctiva of children living in three rural areas in Mexico
}

\author{
Pablo Goldschmidt, ${ }^{1}$ Virginia Vanzzini Zago, ${ }^{2}$ Lidia Diaz Vargas, ${ }^{3}$ Laura \\ Espinoza Garcia, ${ }^{3}$ Carlos Morales Montoya, ${ }^{3}$ Beatríz Peralta, ${ }^{4}$ and Mario Mercado ${ }^{4}$
} Suggested citation
Goldschmidt P, Vanzzini Zago V, Diaz Vargas L, Espinoza Garcia L, Morales Montoya C, Peralta B, et
al. Chlamydia trachomatis in the conjunctiva of children living in three rural areas in Mexico. Rev Panam Salud Publica. 2007:22(1):29-34.

\begin{abstract}
Objectives. Chlamydia trachomatis infections, in the context of extreme poverty, may trigger trachoma. Because the levels of $\mathrm{C}$. trachomatis eye infections in Mexico are unknown, this study sought to determine if $\mathrm{C}$. trachomatis was present in the conjunctiva of children living in three poor, rural areas of the country.

Methods. Clinical diagnosis of conjunctival follicles in children was conducted during the 2004 visual acuity assessment campaigns in rural areas of the states of Chiapas, Oaxaca, and Zacatecas. C. trachomatis detection was carried out by sampling the children with follicles and examining the specimens after Giemsa or microimmunofluorescence (MIF) staining.

Results. A total of 941 children from 6 to 12 years of age were examined in 2004. Of the 484 in Chiapas, 30\% were found to have follicles; of the 181 in Zacatecas, 22\%; and of the 276 in Oaxaca, 42\%. C. trachomatis was detected at levels ranging between $2 \%$ and $5 \%$; positive by Giemsa in $4.5 \%$ of the children with follicles, and by MIF in $15.5 \%$.

Conclusions. Considering that the chlamydiae sampling procedures and detection methods used in this study were not the most sensitive, the results underestimate the chlamydial eye infections and represent a conservative assessment of a potential risk for preventable visual impairment. Because C. trachomatis was detected here at levels similar to those reported for lowendemic trachoma areas, health authorities should be prepared to implement appropriate measures should it be confirmed that the visual health of Mexico's children is at risk.
\end{abstract}

Key words Chlamydia trachomatis, trachoma, eye infections, conjunctivitis, Mexico.

Chlamydiae are obligate intracellular eubacteria that bind to squamocolumnar epithelial cells, where they replicate and persist (1). In the context

1 Laboratoire du Centre National d'Ophtalmologie des Quinze Vingts, Paris, France. Send correspondence to: Pablo Goldschmidt, 28 rue de Charenton, Paris 75012, France; telephone: 3314002 17 95; fax: 331400216 99; e-mail: pablogol@aol.com.

2 Asociación para Evitar la Ceguera, Hospital Sanchez Bulnes, Coyoacán, Mexico.

3 Centro Médico Nacional La Raza, Mexico City, Mexico.

4 Centro Médico Nacional Siglo XXI, Instituto Mexicano del Seguro Social, Mexico City, Mexico. of extreme poverty, the immune reactions induced by repeated or chronic infections trigger inflammatory responses that can lead to trachoma and blindness $(2,3)$. Trachoma is a major cause of visual impairment. It is still detected in areas without basic sanitation services-parts of Africa, the Middle East, Southwest Asia, the Indian subcontinent, and aboriginal communities in Australia. In addition, small focuses of blinding trachoma have been found in Central and South America (4-6).
Before the arrival of Europeans in the Americas, the Mayas described the existence of conjunctival granulations. However, at the 1986 Pan American Congress of Ophthalmology, it was reported that trachoma had been found among the European immigrants to Mexico, but not among the indigenous population (6-8). In 1906, however, trachoma had been found among the indigenous populations, in villages situated in the high valleys of Toluca and Texcoco (8). A high prevalence of tra- 
choma $(>70 \%)$ was also reported among Asian immigrants arriving through the port of Salina Cruz, Mexico, to work on the San Benito to Tapachula railway in the state of Chiapas $(8,9)$. By 1923 , trachoma was reported in almost all of Mexico's states, as well as in several cities located on Guatemala's coasts (10).

Later in the century, severe forms of blinding trachoma were reported. By 1962, 60000 cases were diagnosed in the Tzeltal ethnic group in the Altos de Chiapas area, state of Chiapas $(7,9)$. In 1966, the Dr. Torroella Center for Trachoma and Onchocercosis opened in the city of San Cristobal de las Casas, state of Chiapas. In 1983, it conducted a survey in the rural populations showing that, among those $0-14$ years of age, the prevalence rate of active disease ran as high as $20 \%$. Scars related to trachoma were found in more than half of the population over 50 years of age $(11,12)$.

No further studies have contributed to the overall picture of trachoma prevalence in rural Mexico and the presence of $C$. trachomatis was never confirmed. Likewise, no data regarding levels of C. trachomatis eye infection in Mexico have been reported. The only relevant data available are from genital samples obtained from a female, rural population that had a positive rate of $8 \%(13,14)$.

Persistent chlamydial infection in children with signs of active conjunctival inflammation is considered to be the community pool of active trachoma, (15-17). The aim of this trial was to break new ground by determining if $C$. trachomatis could be detected, with the tools locally available, in the conjunctiva of children presenting follicles in rural areas of three different states of Mexico: Chiapas, Oaxaca, and Zacatecas.

\section{MATERIALS AND METHODS}

\section{Subjects}

All the investigations were performed in accordance with World Medical Association's Declaration of
Helsinki on Ethical Principles for Medical Research involving Human Subjects (18) and the Ley General de Salud de Mexico (19). The protocol for this study was approved by the Ethics Committee of the Instituto Mexicano del Seguro Social (IMSS), Mexico City.

The Proyecto Solidaridad (Solidarity Health Project), funded by the IMSS, offers primary health care services to poor populations living in remote, rural areas beyond the reach of more traditional health care. In 2004, the Children's Visual Health Project, part of the Solidarity Health Project, carried out ophthalmologic testing of school-age children in hospitals that were reachable by paved roadways. Corrective eyeglasses were delivered free of charge following visual acuity testing.

Dwellings and settlements outside the reach of conventional transportation were visited by local health promoters one week prior to testing. Inhabitants were informed of the study and its purpose. Each parent or caretaker had to give formal consent for the child's participation before the child was clinically examined and sampled.

Prior to commencing our research, the local health authorities had indicated that trachoma was absent from the indigenous population. The local health officials and the IMSS representatives authorized only visual acuity testing, followed by a supplementary, rapid clinical examination of the children's inferior conjunctivas for the assessment of follicles. Therefore, the present study should not be likened to a trachoma survey. These exams were performed by trained, volunteer physicians in their third year of residency in ophthalmology. Positive follicles were defined by detection of at least five round swellings of at least $0.5 \mathrm{~mm}$ in diameter that were lighter in color-white, gray, or yellow-than the surrounding conjunctiva.

To avoid cross-contamination, physicians changed gloves between subjects, and were not allowed to handle pens, flashlights, or clinical files, nor register any data. An independent assistant managed the identification of the children and other logistics. Clini- cal data were registered by an independent ophthalmologist.

\section{Sampling procedure}

Specimens were collected from children 6 to 12 years of age presenting follicles. After administration of $1 \%$ tetracaine eye drops, the inferior eye lid was reverted with sterile gauze, and the follicles in the inferior conjunctiva were scraped with sterile, disposable, apyrogenic, stainless-steel, Kimura-like spatulas. After sampling, the children received a local application of chloramphenicol ointment.

\section{C. trachomatis detection}

Although DNA extraction and amplification (NAATs) are known to be more sensitive than Giemsa staining and microimmunofluorescence (MIF) for the detection of Chlamydia in human conjunctiva (20-23), this study's funding would not cover the cost of the most sensitive options. Therefore, two samples were obtained from each child by scraping the conjunctiva. The samples were deposed on coded, multialveolar, black-Teflon slides; fixed with ice-cold acetone/ethanol (1:1) at $-20^{\circ} \mathrm{C}$ for 30 minutes, and dried and conditioned separately in individual, paper envelopes. The fixed slides were kept at $-20^{\circ} \mathrm{C}$ until staining for microscopic examination.

C. trachomatis detection was carried out on masked samples in two laboratories. In the first lab, staff experienced in the identification of typical, intracytoplasmic, epithelial cell basophilic inclusions examined smears stained with Giemsa ( $\mathrm{pH} 7.4$ ) and determined whether each was positive or negative. In the second lab, MIF was conducted by incubating the fixed specimens with a FITC-labeled monoclonal antibody diluted in a Blue Evans solution (counterstaining) according to manufacturer's instructions (Biomérieux, Lyon, France).

Two microbiologists with confirmed experience in direct diagnosis of chlamydial infections by MIF examined 
each sample and considered the result positive when 25 or more epithelial cells per smear were identified (counter stain) and associated with three or more green, fluorescent images (as appearing in the positive control slides). Yellowish images were considered negative; smears with fewer than 25 cells, noninterpretable.

\section{Statistical analysis}

Intergroup and intragroup differences were analyzed by analysis of variance (ANOVA). Non-parametric variables were studied by the KruskalWallis test and correlation by Spearman's test.

\section{RESULTS}

Visual acuity was assessed in a total of 941 children 6 to 12 years of age in three rural areas: Chiapas, 484; Zacatecas, 181; and Oaxaca, 276. Clinical assessment of inflammatory signs in the inferior conjunctiva showed follicles in $30 \%, 22 \%$, and $42 \%$ of the children, respectively.

Tables 1, 2, and 3 show that although the number of children tested varied from area to area, age- and sexdistribution were the same. No significant differences were found for the overall results when comparing the age or the sex of the children $(P=0.96$ and 0.81 , respectively). Interaction between age/sex, age/state, and sex/ state were statistically insignificant $(P=0.99,0.23$, and 0.28 , respectively).

For the subgroup of children with follicles, the differences for age and sex were not statistically significant $(P=0.68$ and 0.94 , respectively) for the three groups (intra- and intersubgroup). No significant interactions were detected while comparing age/ sex or sex/location $(P=0.99$ and 0.37 , respectively) for the whole subgroup of children with follicles. Nevertheless, in Oaxaca (where follicles were detected in $42 \%$ ), a statistically significant difference in the number of affected children was found when comparing it with the other two areas
(Chiapas, 21\%; Zacatecas, 30\%) $(P=$ 0.001).

In all three states, the rate of children with follicles to the total number of children examined was similar in each of the seven age groups (one group for each year from 6 to 12 years) (Tables 1-3). In Zacatecas, all but one age group had a rate under 30\%; in Oaxaca, all age groups had more than $28 \%$ with follicles; and in Chiapas, the rate was always greater than $25 \%$ in the children less than 10 years of age, and always less than $25 \%$ in those 10 or older. The interaction of age/state had a follicle rate that was statistically significant $(P=0.002)$.

The overall analysis shows that of the 245 children with follicles, C. trachomatis was detected by MIF in 15.5\% of the samples and by Giemsa staining in only $4.5 \%$. C. trachomatis detection rates by MIF were significantly higher $(P=0.0001)$ and showed a better correlation with the proportion of children with follicles (Spearman's rho: 0.522; $P=0.001)$ than the levels obtained with Giemsa staining (Spearman's rho: $0.273 ; P=0.107)$. The difference in the number of positive samples was not statistically significant $(P=0.650)$ for the two techniques regarding $\operatorname{sex}(P=$ $0.483)$ or age $(P=0.090)$.

\section{DISCUSSION AND CONCLUSIONS}

Trachoma is thought to be endemic in rural Mexico; however, its extent, severity, and infection rate are unknown. No surveys were conducted during the late 1980s or 1990s, and the question of the real impact of ophthalmic chlamydial infections has remained unanswered. In this context, the Visual Health Program team was only allowed to conduct a rapid, clinical observation of the children's conjunctivas, far short of the World Health Organization (WHO) guidelines for trachoma assessment.

In addition to the visual acuity testing, the ophthalmologists examined the inferior conjunctival fornix to assess follicles and to sample when positive. Because bacteria other than Chlamydia such as, fungi, viruses, aller-

\begin{abstract}
TABLE 1. Distribution by age, sex, presence of follicles, and detection of Chlamydia trachomatis by microimmunofluorescence (MIF) or Giemsa staining, of children 6 to 12 years of age in rural areas of the state of Chiapas, Mexico, 2004
\end{abstract}

\begin{tabular}{|c|c|c|c|c|}
\hline Age (years)/Sex & Total & $\begin{array}{c}\text { Follicles } \\
\text { in inferior tarsus }\end{array}$ & MIF-positive & Giemsa-positive \\
\hline \multicolumn{5}{|l|}{6} \\
\hline Female & 24 & 11 & 2 & 0 \\
\hline Male & 40 & 17 & 3 & 0 \\
\hline \multicolumn{5}{|l|}{7} \\
\hline Female & 40 & 21 & 3 & 2 \\
\hline Male & 25 & 9 & 0 & 0 \\
\hline \multicolumn{5}{|l|}{8} \\
\hline Female & 39 & 16 & 3 & 0 \\
\hline Male & 31 & 9 & 4 & 0 \\
\hline \multicolumn{5}{|l|}{9} \\
\hline Female & 46 & 20 & 3 & 2 \\
\hline Male & 29 & 16 & 2 & 0 \\
\hline \multicolumn{5}{|l|}{10} \\
\hline Female & 31 & 5 & 1 & 0 \\
\hline Male & 30 & 5 & 2 & 1 \\
\hline \multicolumn{5}{|l|}{11} \\
\hline Female & 38 & 4 & 0 & 0 \\
\hline Male & 32 & 7 & 1 & 0 \\
\hline \multicolumn{5}{|l|}{12} \\
\hline Female & 40 & 4 & 0 & 0 \\
\hline Male & 39 & 2 & 1 & 0 \\
\hline Total & 484 & 146 & 25 & 5 \\
\hline
\end{tabular}


TABLE 2. Distribution by age, sex, presence of follicles, and detection of Chlamydia trachomatis by microimmunofluorescence (MIF) or Giemsa staining, of children 6 to 12 years of age in rural areas of the state of Zacatecas, Mexico, 2004

\begin{tabular}{|c|c|c|c|c|}
\hline Age (years)/Sex & Total & $\begin{array}{c}\text { Follicles } \\
\text { in inferior tarsus }\end{array}$ & MIF-positive & Giemsa-positive \\
\hline \multicolumn{5}{|l|}{6} \\
\hline Female & 9 & 1 & 0 & 0 \\
\hline Male & 13 & 2 & 0 & 0 \\
\hline \multicolumn{5}{|l|}{7} \\
\hline Female & 14 & 4 & 1 & 1 \\
\hline Male & 16 & 4 & 1 & 1 \\
\hline \multicolumn{5}{|l|}{8} \\
\hline Female & 12 & 1 & $0^{a}$ & 0 \\
\hline Male & 12 & 2 & 0 & 0 \\
\hline \multicolumn{5}{|l|}{9} \\
\hline Female & 14 & 2 & $0^{\mathrm{a}}$ & 0 \\
\hline Male & 16 & 3 & 0 & 0 \\
\hline \multicolumn{5}{|l|}{10} \\
\hline Female & 12 & 3 & $0^{a}$ & 0 \\
\hline Male & 12 & 3 & 1 & 1 \\
\hline \multicolumn{5}{|l|}{11} \\
\hline Female & 13 & 2 & 1 & 0 \\
\hline Male & 15 & 4 & 0 & 0 \\
\hline \multicolumn{5}{|l|}{12} \\
\hline Female & 11 & 2 & 0 & 0 \\
\hline Male & 12 & 6 & 0 & 0 \\
\hline Total & 181 & 39 & 4 & 3 \\
\hline
\end{tabular}

a Noninterpretable results (less than 50 cells/smear).

gens, and pollutants, may have induced the formation of follicles in the inferior fornix, the prevalence rates for

TABLE 3. Distribution by age, sex, presence of follicles, and detection of Chlamydia trachomatis by microimmunofluorescence (MIF) or Giemsa staining, of children 6 to 12 years of age in rural areas of the state of Oaxaca, Mexico, 2004

\begin{tabular}{|c|c|c|c|c|}
\hline Age (years)/Sex & Total & $\begin{array}{c}\text { Follicles } \\
\text { in inferior tarsus }\end{array}$ & MIF-positive & Giemsa-positive \\
\hline \multicolumn{5}{|l|}{6} \\
\hline Female & 22 & 9 & 0 & 0 \\
\hline Male & 15 & 7 & 1 & 1 \\
\hline \multicolumn{5}{|l|}{7} \\
\hline Female & 14 & 6 & 1 & 0 \\
\hline Male & 14 & 7 & 1 & 0 \\
\hline \multicolumn{5}{|l|}{8} \\
\hline Female & 15 & 8 & 1 & 0 \\
\hline Male & 18 & 9 & $0^{\mathrm{a}}$ & $0^{a}$ \\
\hline \multicolumn{5}{|l|}{9} \\
\hline Female & 21 & 9 & 2 & 1 \\
\hline Male & 19 & 7 & $0^{\mathrm{a}}$ & 0 \\
\hline \multicolumn{5}{|l|}{10} \\
\hline Female & 24 & 12 & 1 & 1 \\
\hline Male & 32 & 14 & $0^{a}$ & 0 \\
\hline \multicolumn{5}{|l|}{11} \\
\hline Female & 12 & 7 & 1 & 0 \\
\hline Male & 14 & 4 & 1 & 0 \\
\hline \multicolumn{5}{|l|}{12} \\
\hline Female & 28 & 9 & 0 & 0 \\
\hline Male & 28 & 8 & 0 & 0 \\
\hline Total & 276 & 116 & 9 & 3 \\
\hline
\end{tabular}

\footnotetext{
a Noninterpretable results (less than 50 cells/smear).
}

can they be compared to results reported in trachoma surveys conducted according to $\mathrm{WHO}$ recommendations.

The present study is the first to show that C. trachomatis is present at levels ranging between $2 \%$ and $5 \%$ in the conjunctiva of children ages 6 to 12 years old living in three rural areas of Mexico, where low income and limited sanitation are widespread.

It should be recognized that the study results underestimate the actual rate of chlamydial eye infections for four reasons. First, a thorough evaluation of conjunctival inflammation could not be performed due to a lack of appropriate equipment (i.e., magnifying glass, flashlight). Second, trachoma sampling and testing are ideally carried out in the upper tarsal conjunctiva by reverting the upper-lid and assessing the number, morphology, and size of follicles with the help of a magnifying glass. Even so, in this study, where sampling and testing were carried out on the inferior conjunctival fornix and assessed without a magnifying device, the number of children with follicles and carrying C. trachomatis in the conjunctiva was substantial. Third, the rate of chlamydial eye infections may have been underestimated by the sampling procedure. The superficial epithelium of the inferior fornix-scraped during the sampling-may not have accurately represented the bacterial load of the conjunctiva, and therefore, would not have efficiently recovered Chlamydia. Finally, the most sensitive methods for C. trachomatis diagnosis are based on nucleic acid amplification technology (NAAT). Such tests can detect as few as one organism per assay, whereas the limit of detection for conventional nonculture methods is 10 or more organisms (20-26).

Performing NAAT-based testing requires at least one clean room for DNA extraction, and amplification equipment that is specifically dedicated to chlamydial DNA diagnosis. However, in the absence of appropriate conditions and equipment, $C$. trachomatis can be detected by direct, cytological examination of conjunctival swabs. Reading of Giemsa-stained specimens requires 
only a light microscope, but has reduced sensitivity. Staining the smears with specific, fluorescent-tagged, monoclonal antibodies improves sensitivity, but requires a fluorescence microscope (23-25). In India, where slides were examined to diagnose clinically suspected cases of trachoma, MIF was found to be 2.52 times more sensitive than Giemsa staining for confirming C. trachomatis (22). In the United States of America, a prospective comparison of four currently available diagnostic tests for C. trachomatis infection in clinically suspected cases of chlamydial conjunctivitis showed that detecting inclusions by Giemsa staining had a sensitivity and specificity of $43 \%$ and $100 \%$, respectively, while the monoclonal fluorescent antibody had $57 \%$ and $81 \%$, respectively (cell culture on McCoy cells was the reference method) (23).

In the present study, the MIF detection rates for $C$. trachomatis were also almost three times higher than the Giemsa staining rates. However, the C. trachomatis rate in rural Mexican children is not different from that found in the low trachoma prevalence areas of other countries $(5,6,20,26-28)$. Nevertheless, predictions of potential clinical degradation of visual function cannot be made just because C. trachomatis can be detected in the conjunctiva of asymptomatic children $(3,4$, 15-17). The mere presence of C. trachomatis in conjunctival epithelial cells is not enough to provoke trachoma and blindness. Host factors associated with poverty and hygiene play a key role in the establishment and course of clinical disease. The prognosis for chlamydial infection for the area in which a child is born, can be different from that of the area in which he grows up.

In industrialized countries, chlamydial eye infections in children do not lead to blindness because hygiene, medical care, and appropriate antibiotic treatment can be administered on time, limiting the fibrotic effects of a prolonged infection $(17,29-30)$. For example, C. trachomatis was detected by MIF in $8 \%$ of the 162 newborns at 14 primary health centers from public hospitals in the city of Santiago de Chile, Chile (31) and in $41 \%$ of 180 babies with uni- or bilateral neonatal conjunctivitis in the south of Italy (32), but there has not been a single case of trachoma reported in either of these countries for over 30 years.

In the state of Chiapas, however, the detection of C. trachomatis in children's conjunctivas requires a different approach because in the early 1980s trachoma was reported in the state's Chaonil community in $24 \%$ of 475 children examined and in $8 \%$ of the trachomatous population with trichiasis (no data regarding chlamydial infections were produced) $(11,12,33)$.

The children participating in the present study came from villages in the mountainous terrain of the state of Chiapas, at an elevation of at least 2400 meters above sea level, with cool and damp weather year-round. Their homes were dispersed over a large area, isolated in the mountains. Out of reach by any kind of ground transportation, most children participating in the study arrived to the IMSS health centers by boat or by foot after walking for more than 60 minutes. None of the children examined in Chiapas, who belonged to the Chamula, Tzotzil, and Tzental ethnic groups spoke Mexico's official national language (Spanish) or had ever been seen by a physician.

A far different picture was found in Zacatecas and Oaxaca, where trachoma has not been reported recently. In these two study areas, almost all the children came from dwellings that had electricity and that were accessible by paved roads. In addition, either the children themselves or their parents had some level of formal education, had been seen by a physician or health promoter at least once, and reported having been vaccinated.

The results of this study represent a minimal assessment of the level of chlamydial infection in the conjunctivas of children living in rural areas of Mexico. Even with its limitations, this study should prompt health authorities to carry out comprehensive surveys, according to international standards, and engage in preventive and curative actions that will ensure the future ocular health of children in Mexico.

Acknowledgments. We are thankful to the physicians, nurses, and health promoters of the "Plan de Salud Visual" (Visual Health Plan) of the Proyecto Solidaridad del Instituto Mexicano del Seguro Social for their help in carrying out this study. We also wish to thank the physicians, nurses, and health promoters at the Hospital Regional San Andrés de San Cristóbal de Ecatepec, Estado de Chiapas; the Hospital Rural de Solidaridad de Tlacolula de Matamoros, Estado de Oaxaca; the Hospital Rural Solidaridad IMSS, Zacatecas; and the Servicio de Infectologia del Centro Medico Nacional La Raza, Mexico City.

For the financial support obtained from the Departamento de Cooperacion Cientifica de la Secretaria de Relaciones Exteriores de Mexico, we are grateful to Ms. Luz Elena Baños Rivas and Ms. Elisabeth Colin; for the statistical analyses, Eliane Albuisson, of the Université d'Angers, France; and for the purchase of monoclonal antibodies, the Laboratoires Thea, France.

\section{REFERENCES}

1. Iliffe-Lee ER, McClarty G. Glucose metabolism in Chlamydia trachomatis: the 'energy parasite' hypothesis revisited. Mol Microbiol. 1999;33(1):177-87.

2. Bobo LD, Novak N, Munoz B, Hsieh YH, Quinn TC, West S. Bobo. Severe disease in children with trachoma is associated with persistent Chlamydia trachomatis infection J Infect Dis. 1997;(6):1524-30.

3. Dawson CR, Juster R, Marx R, Daghfous MT, Ben Djerad A. Limbal disease in trachoma and other ocular chlamydial infections: risk factors for corneal vascularisation. Eye. 1989;3 (Pt 2):204-9.
4. Mabey DC, Solomon AW, Foster A. Trachoma. Lancet. 2003;362(9379):223-9.

5. Pages R. In which countries is trachoma a problem? Rev Int Trach Pathol Ocul Trop Subtrop Santé Publique. 1981;(3-4):77.

6. West S, Muñoz B. Epidemiology of trachoma. In: Johnson GJ, Minassian DC, Weale R, edi- 
tors. The epidemiology of eye disease. Chapman \& Hall Medical. London, United Kingdom. 1998;119-35.

7. Torroella JJ, Portillo C. Hallazgo en una zona en el estado de Chiapas con enfermos tracomatosos. An Soc Mex Oftalmol. 1965(3): 161-8.

8. Valenzuela F. Las causas de la invasión del tracoma en México. An Soc Mex Oftalmol. 1931;(15) (16):450-66.

9. Torroella JJ, Portillo C. Trachoma in the Republic of Mexico. Rev Int Trach Pathol Ocul Trop Subtrop Sante Publique. 1983;59-65.

10. Velez D, Chavira R. Distribución geográfica del tracoma en México. An Soc Mex Oftalmol. 1923;(5):109-13.

11. Taylor HR, Velasco FM, Munoz EC, Ruvalcaba AM, Greene BM. Trachoma in Chiapas, Mexico. Rev Int Trach Pathol Ocul Trop Subtrop Sante Publique. 1983;17-27.

12. Taylor HR, Velasco FM, Sommer A. The ecology of trachoma: an epidemiological study in southern Mexico. Bull World Health Organ. 1985;63(3):559-67.

13. Baldwin SB, Djambazov B, Papenfuss $M$, Abrahamsen M, Denman C, Guernsey de Zapien J, et al. Chlamydial infection in women along the US-Mexico border. Int J STD AIDS. 2004;(12):815-21.

14. Hernandez Tepichin G. The prevalence of Chlamydia trachomatis infection is probably higher than reported. Salud Publica Mex. 2000;42(5):373-4.

15. West SK. Trachoma: new assault on an ancient disease. Prog Retin Eye Res. 2004;(4): 381-401.

16. Bailey R, Duong T, Carpenter R, Whittle H, Mabey D. The duration of human ocular Chlamydia trachomatis infection is age dependent. Epidemiol Infect. 1999;(3):479-86.
17. Hsieh YH, Bobo LD, Quinn TC, West SK. Risk factors for trachoma: 6-year follow-up of children aged 1 and 2 years. Am J Epidemiol. 2000;152(3):204-11.

18. World Medical Association. Declaration of Helsinki on ethical principles for medical research involving human subjects. Available from: http://www.wma.net/e/policy/b3. Accessed 26 July 2007.

19. Government of Mexico. Ley General de Salud de Mexico, 1997. Available from: http:/ /www. salud.gob.mx/unidades/cdi/listcompil.html Accessed 26 July 2007.

20. Taylor-Robinson D. Evaluation and comparison of tests to diagnose Chlamydia trachomatis genital infections. Hum Reprod. 1997;(11 Suppl):113-20.

21. Black CM. Current methods of laboratory diagnosis of Chlamydia trachomatis infections. Clin Microbiol Rev. 1997;(1):160-84.

22. Elnifro EM, Storey CC, Morris DJ, Tullo AB. Elnifro. Polymerase chain reaction for detection of Chlamydia trachomatis in conjunctival swabs. Br J Ophthalmol. 1997;(6):497-500.

23. Sheppard JD, Kowalski RP, Meyer MP, Amortegui AJ, Slifkin M. Immunodiagnosis of adult chlamydial conjunctivitis. Ophthalmology. 1988;95(4):434-42.

24. Baveja UK, Hiranandani MK, Talwar P, Sen DK. Laboratory techniques for diagnosis of chlamydial infections of the eye. J Commun Dis. 1997;(3):247-53.

25. Lin J, Li Y, Zhang J, Feng G, Zhang P, Zheng $\mathrm{H}$, Zheng. J. Rapid diagnosis of chlamydial conjunctivitis in laboratory. Yan Ke Xue Bao. 1999;15(3):191-4.

26. Kay ID, Palladino S, Alexander R, Leahy BJ, Pearman JW. Evaluation of a commercial polymerase chain reaction assay for the detec- tion of Chlamydia trachomatis. Diagn Microbiol Infect Dis. 1997;28(2):75-9.

27. Thein J, Zhao P, Liu H, Xu J, Jha H, Miao Y, Pizzarello L, Tapert L, Schachter J et al. Does clinical diagnosis indicate ocular chlamydial infection in areas with a low prevalence of trachoma? Ophthalmic Epidemiol. 2002;(4): 263-9.

28. Muñoz B, West S. Blindness and visual impairment in the Americas and the Caribbean. Br. J. Ophthalmol. 2002 (86) 498-504.

29. Negrel AD, Mariotti SP, Thylefors B. World Health Organization alliance for the elimination of trachoma. Rev Int Trach Pathol Ocul Trop Subtrop Santé Publique. 1997;74:109-17.

30. Schachter J, Dawson C. Elimination of blinding trachoma. Curr Opin Infect Dis. 2002;15: 491-5.

31. Valencia C, Prado V, Rios M, Cruz MA, Pilorget JJ. Prevalence of the Chlamydia trachomatis in neonatal conjunctivitis determination by indirect fluorescence and gene amplification. Rev Med Clin. 2000;(7):758-65.

32. Salpietro CD, Bisignano G, Fulia F, Marino A, Barberi I. Chlamydia trachomatis conjunctivitis in the newborn. Arch Pediatr. 1999;6(3): 317-20.

33. Wilson M, Keyvan-Larijani E, Millan-Velasco F, Tielsch JM, Taylor HR. The epidemiology of trachoma in Chiapas (Mexico). Rev Int Trach Pathol Ocul Trop Subtrop Santé Publique. 1987;(64):159-74.

Manuscript received 17 July 2006. Revised version accepted for publication 26 May 2007.
RESUMEN

\section{Chlamydia trachomatis en la conjuntiva de niños de tres zonas rurales de México}

Palabras clave
Objetivos. En un contexto de pobreza extrema, la infección por Chlamydia trachomatis puede desencadenar el tracoma. Debido a que se desconocen los niveles de infección ocular con C. trachomatis en México, el objetivo de este estudio fue determinar la presencia de $C$. trachomatis en la conjuntiva de niños de tres zonas rurales pobres de México.

Métodos. El diagnóstico clínico de folículos conjuntivales en los niños se llevó a cabo durante la campaña de evaluación de la agudeza visual en áreas rurales de los estados de Chiapas, Oaxaca y Zacatecas en 2004. Para la detección de C. trachomatis se tomaron muestras de los niños con folículos y se analizaron mediante la tinción de Giemsa o microinmunofluorescencia (MIF).

Resultados. En total se examinaron 941 niños de 6 a 12 años de edad en 2004. Se observaron folículos en 30\% de los 484 niños de Chiapas, en $22 \%$ de los 181 de Zacatecas y en $42 \%$ de los 276 niños de Oaxaca. Se detectó C. trachomatis en niveles entre $2 \%$ y $5 \%$; de los niños con folículos, $4,5 \%$ resultaron positivos por Giemsa y $15,5 \%$ por MIF.

Conclusiones. Estos resultados subestiman el nivel de infección ocular por clamidia, ya que los procedimientos de muestreo y los métodos de detección de clamidia empleados en este estudio no eran los más sensibles, por lo que representan una valoración conservadora del riesgo de trastornos visuales prevenibles. Como los niveles de C. trachomatis encontrados son similares a los informados para áreas de baja endemia de tracoma, las autoridades de salud deben estar listas para implementar medidas apropiadas si se confirmaran los riesgos para la salud visual de los niños mexicanos.

Chlamydia trachomatis, tracoma, infecciones del ojo, conjuntivitis, México. 